\title{
DO UNIVERSAL AO PARTICULAR: UMA DISCUSSÃO SOBRE O MASCULINO NA PSICANÁLISE
}

Ronaldo Sousa Sampaio

Nesta tese discutimos o processo de constituição subjetiva dos homens apoiados na literatura psicanalítica e na contribuição das ciências sociais. $\mathrm{Na}$ psicanálise, Freud, influenciado pelas premissas sexistas rousseaunianas, tendeu discutir a subjetividade masculina sob o prisma do paradigma falocêntrico, tendo sido Lacan quem mais deu continuidade a este legado. Os trabalhos psicanalíticos de Robert Stoller e Ralph Greenson e sua revisão crítica por Irene Fast e Michael J. Diamond oferecem novas perspectivas para o estudo das questôes masculinas na psicanálise que se afastam do paradigma falocêntrico e se mostram mais adequadas à compreensão do sujeito masculino contemporâneo.

BANCA:

Claudia Amorim Garcia (Orientadora)

Bernardo Jablonski

Carlos Augusto Peixoto Junior

Silvia Alexim Nunes

Sócrates Alvares Nolasco

Data da defesa: 31/03/2010 